Volume 18, No 4 International Journal of Radiation Research, October 2020

\title{
Ameliorative role of melatonin against cypermethrin or gamma irradiation induced testicular damage in male rats
}

\author{
E.M. Kamal El-Dein and L.M. Anees*
}

Health Radiation Research Department, National Center for Radiation Research and Technology (NCRRT), Egyptian Atomic Energy Authority, Cairo, Egypt

\section{- Original article}

\section{*Corresponding authors:}

Lobna Mohammed Anees, Ph.D., E-mail:

Lobnaanis@gmail.com

Revised: January 2020

Accepted: February 2020

Int. J. Radiat. Res., October 2020; 18(4): $765-776$

DOI: 10.18869 /acadpub.ijrr.18.4.765

\begin{abstract}
Background: This work aimed at studying the protective effect of melatonin (MLT) against cypermethrin or $\gamma$-radiation induced testicular damage. Material and Methods: Thirty six Male rats were randomly divided into 6 groups. Control group, group treated with MLT (10 mg/Kg b. wt.), group administered cypermethrin $(25 \mathrm{mg} / \mathrm{kg}$. b. wt.), group 4 was exposed to fractionated whole body $\gamma$-radiation (the sum=8 Gy), group 5 was coadministered with MLT (10 mg/Kg .b. wt.) and cypermethrin ( $25 \mathrm{mg} / \mathrm{kg}$ b. wt.) and finally group 6 rats were supplemented with MLT (10 $\mathrm{mg} / \mathrm{Kg} . b$. wt.) and subsequently administered fractionated $y$-radiation(the sum $=8 \mathrm{~Gy}$ ). After treatment for 29 successive days, all animals groups were investigated for hormonal assay, sperm quality, oxidative indices and histological examination of testicular tissues. Results: Rat's treatment with $\gamma$-radiation or Cypermethrin showed a significant decrease in body weight, testis, epididymis, ventral prostate and seminal-vesicles weights. Also, a significant increase was observed in the levels of TBARS and $\mathrm{H}_{2} \mathrm{O}_{2}$, while a significant reduction occurred in the activity of SOD, CAT and GSH content in testis tissues, in addition to a significant decrease in testosterone hormone. On the other hand, a significant increase occurred in FSH and prolactin hormones .moreover, a significant decrease in sperm count and motility occured beside a significant increase in abnormal forms. Pretreatment of rats with MLT improved the disturbances induced in the tested parameters of rats either received cypermethrin or $\gamma$-irradiation. Conclusion: According to the present findings, the ameliorative role of MLT is obvious against cypermethrin or $\mathrm{y}$-irradiation induced testicular damage probably, due to its antioxidative properties.
\end{abstract}

Keywords: Melatonin, Ionizing radiation, cypermethrin, antioxidants, testis, hormones.

\section{INTRODUCTION}

Attention has been drawn to the role of oxygen toxicity and free radical reaction in association with fertility potential, which can cause oxidative stress to the lipid constituents of the cell membrane. Reactive oxygen species (ROS) was shown to induce infertility due to imperfect sperm function (1). Lipids, proteins, and nucleic acids are endogenous particles influenced by ROS. Additionally, ROS affect cellular proliferation through moderating components of the signaling pathways (2). The primary aspect in male sterility is oxidative stress. As spermatogenic lineage cells are predominantly susceptible to radiation-induced reactive oxygen species (ROS) since they are constantly beneath meiosis or mitosis. This reveals that testes are extremely radiosensitive tissues with a broad variety of radiosensitive 
germ cells (3). The testicular tissue contains an elaborate array of antioxidant enzymes and free radical scavenger to ensure that the spermatogenic and steroidogenic functions are not disturbed (4). Nevertheless, an extensive diversity of exogenous and endogenous influences are recognized as competent to disturb these protections besides compromising male productiveness by producing free radicals in testicles (5). Thus, protection of reproductive systems potential and heredity in the germ cells of these mammals against radiation damage is recommended (6).

The exposure of humans to natural pollutants which adversely disturb the male regenerative structure is expanding (7). It has been claimed that manufactured pyrethroids have hormonal actions and categorized as endocrine-disrupting compounds (EDCs), which possibly posture a risk to humans and natural environment (8). Pyrethroids show estrogenic activities in addition to anti-androgenic activities (9), particularly those related to positive male regenerative injuries including testicular injuries, diminished sperm count, sperm morphologic anomaly, sperm motility variations, also genotoxic impacts (10).

Cypermethrin is a dynamic manufactured pyrethroid pesticide which is usually utilized to control different pests in farming, community wellbeing and in veterinary preparation in contradiction of ectoparasites. The chemical form of which is (+/-) alphacyano - (3 phenoxyphenyl) methyl $(+)$ - cis, Trans - 3 (2, 2 - dichloroethenyl) - 2, 2 - dimethylcyclo propane carboxylate (11). Cypermethrin can initiate injuries to spermatogenesis and seminiferous tubules structure within the male rats; the damages can be ascribed to the decreased androgenic receptors upregulation (12). Wang etal. ${ }^{(13)}$ showed that testicular StAR expression downregulation by cypermethrin introduction throughout adolescence considerably interrupts testosterone production. The diminished testosterone production could be associated with spermatogenesis induced damage by cypermethrin in mice.

Melatonin (MLT) (N - acetyl - 5 - methoxytryptamine) is primarily discharged from the pineal gland. It is a neurohormone derivative from tryptophan. MLT contributed in several homeostatic functions, for instance circadian rhythms and reproduction regulation (14), through its activity at several levels of the hypothalamic-pituitary-gonadal axis (15). Also, it has antiapoptotic and antioxidant properties against oxidative stress in numerous investigational and medical disorders with an enormous safety margin upon its administration $(16,17)$. MLT promptly scavenges the utmost harmful reactive nitrogen and oxygen species, as well as hydrogen peroxide $\left(\mathrm{H}_{2} \mathrm{O}_{2}\right)$, the peroxynitrite anion, and hydroxyl radical. It arouses levels of antioxidant enzymes through messenger RNA (mRNA) stimulation (18).

In view of the above facts, the authors hypothesize that MLT administration might have protective effects against cypermethrin or $\gamma$-irradiation-induced testicular damage by intervening with oxidative processes. Therefore, the current study was conducted to determine the activity of MLT against cypermethrin or $\gamma$-irradiation induced testicular damage.

\section{MATERIALS AND METHODS}

\section{Melatonin and other chemicals}

Melatonin was purchased from Sigma-Aldrich Co., (St Louis, Missouri, USA) .It was dissolved in normal saline, then gavaged to animals $(0.5 \mathrm{ml})$ at a dose of $(10 \mathrm{mg} / \mathrm{kg}$ body weigh/day.) for 29 successive days.

Cypermethrin was obtained from the Central Laboratory of Pesticide, Dokki, Egypt, and dissolved in corn oil , then administered orally at a dose of $25 \mathrm{mg} / \mathrm{Kg} . \mathrm{b} . w \mathrm{l}\left(\mathbf{1} / \mathbf{1 0} \mathrm{LD}_{50}\right)$ for 29 successive days $(13,19)$.

Trichloroacetic acid (TCA), thiobarbituric acid (TBA), reduced glutathione (GSH), glacial metaphosphoric acid (Gmpa), 5,5 -dithiobis-(2nitrobenzoic acid) (DTNB), were purchased from Sigma-Aldrich Co, MO, USA. All other chemicals and solvents were of the highest purity grade available.

\section{Animals}

Male albino rats (Sprague Dawley) weighing

Int. J. Radiat. Res., Vol. 18 No. 4, October 2020 
(130 - $150 \mathrm{~g}$ ), were obtained from the Egyptian Holding Company for Biological Products and Vaccines (Cairo, Egypt). Animals remained held underneath standard research laboratory conditions throughout the experimental period. Rats were supplied with tap water and standard food pellets.

\section{Animal ethical consideration}

All animals were maintained under adjusted environmental conditions (temperature, relative humidity as well as light/dark cycle) in accordance with the "Guide for the Care and Use of Laboratory Animals" prepared by the National Academy of Sciences, and published by the National Institutes of Health (NIH publications No, 8023, revised 1978).

\section{Radiation treatment}

Whole body $\gamma$-irradiation of animals was performed at the NCRRT using an AECL ( ${ }^{137}$ Cesium) Gamma Cell-40 biological irradiator. Animals were submitted to fractionated whole body $\gamma$-radiation; 1 Gy installment at $1^{\text {st }}, 5^{\text {th }}, 9^{\text {th }}$, $13^{\text {th }}, 17^{\text {th }}, 21^{\text {th }}, 25^{\text {th }}$ and $29^{\text {th }}$ days (the $\operatorname{sum}=8 \mathrm{~Gy}$ ) at dose rate $0.61 \mathrm{~Gy} / \mathrm{min}$.

\section{Experimental design}

Rats were randomly divided into 6 groups ( $n=6$-rats/group). Group (1) assisted as controls. Group (2) Rats were supplied orally with MLT at a daily dose of $10 \mathrm{mg} / \mathrm{Kg}$ b.wt. for 29 successive days. Group (3) Rats were administered orally at a daily dose of cypermethrin $(25 \mathrm{mg} / \mathrm{kg}$. b.wt.) for 29 successive days. Group (4) were exposed to fractionated whole body $\gamma$-radiation; 1 Gy installment at $1^{\text {st }}, 5^{\text {th }}, 9^{\text {th }}, 13^{\text {th }}, 17^{\text {th }}, 21^{\text {th }}, 25^{\text {th }}$ and 29th days (the sum=8 Gy). Group (5) Rats received orally MLT $(10 \mathrm{mg} / \mathrm{Kg}$.b.wt) and at the same time, they were treated with cypermethrin (25 mg/kg b.wt).Group (6) Rats of this group were supplemented orally with MLT (10 mg/ $\mathrm{Kg}$.b.wt) and at the same time, they were exposed to the fractionated gamma-irradiation dose ( 1 Gy every 4 days for 29 days). The dose of melatonin was based on earlier studies (20).

\section{Sample preparation and biochemical analysis}

One day post the last treatment, rats from each group were weighed and sacrificed by cervical dislocation. The blood samples were collected from intra-cardiac puncture and serum was separated by centrifugation using Sorvall TC centrifuge, (Hamburg, Germany) at $750 \mathrm{~g}$ at room temperature for $10 \mathrm{~min}$., which were then stored at $-80^{\circ} \mathrm{C}$ as aliquots for further analysis. The abdomen was dissected to remove the testes from each animal to be separated, then weighed immediately and homogenized with 10 volume of phosphate buffer, PH 7.2 using Teflon homogenizer Glas-Col, Terre Haute, Ind., USA the homogenates were centrifuged at $10,000 \mathrm{~g}$ for $15 \mathrm{~min}$ and aliquots of supernatants were separated for different biochemical assays. Additional male adjunct sex tissues (epididymis, seminal vesicles also ventral prostate) were detached instantly and washed from adhering fats. Formerly, epididymis and seminal vesicles were prepared for sperm count and sperm morphology test.

\section{Assessment of oxidative stress}

Lipid peroxidation (LPX) end product as thiobarbituric acid reactive substances (TBARS) was estimated according to the method of Yoshioka et al. (21). Briefly, $0.5 \mathrm{ml}$ of tissue homogenate was added to $2.5 \mathrm{ml}$ of $20 \%$ TCA and $1.0 \mathrm{ml}$ of $0.67 \% \mathrm{TBA}$, and then the reaction mixture was vigorously shaken and heated for $30 \mathrm{~min}$ in a boiling water bath followed by a rapid cooling and addition of $4.0 \mathrm{ml}$ of $\mathrm{n}$-butanol with shaking. The alcohol layer was separated by centrifugation at $\times 2000 \mathrm{~g}$ for $10 \mathrm{~min}$, and the absorbance was measured at $535 \mathrm{~nm}$ using 1, 1, 3, 3-tetraethoxypropane as a standard.

Glutathione (GSH) content was determined as described by Beutler et al. (22). In brief, $1.0 \mathrm{ml}$ of tissue homogenate was mixed with $3.0 \mathrm{ml}$ of precipitating solution composed of $1.67 \mathrm{~g} \mathrm{Gmpa,}$ $0.20 \mathrm{~g} \mathrm{Na}^{2} \mathrm{EDTA}$, and $30 \mathrm{~g} \mathrm{NaCl}$ dissolved in 100 $\mathrm{ml}$ water. The mixture was centrifuged at $\times 3000 \mathrm{~g}$ for $10 \mathrm{~min}$, then $0.5 \mathrm{ml}$ of the supernatant was mixed with $2.0 \mathrm{ml}$ of $0.2 \mathrm{M}$ phosphate buffer and $0.25 \mathrm{ml}$ of $0.04 \%$ DTNB in $1 \%$ sodium citrate solution. The absorbance of the yellow color was measured at $412 \mathrm{~nm}$ within 4 min.

Hydrogen peroxide $\left(\mathrm{H}_{2} \mathrm{O}_{2}\right)$ was specified 
using a commercial kit from Biodiagnostic ${ }^{\circledR}$, Egypt according to the method of Pick and Keisari (23).

Superoxide dismutase (SOD) activity was evaluated using Biodiagnostic ${ }^{\circledR}$ Company, Egypt kit based on the model of Minami and Yoshikawa (24) and catalase (CAT) was specified using a commercial kit from Biodiagnostic ${ }^{\circledR}$, Egypt according to the method of Johansson and Borg (25). The absorbance was calculated using T60 UV-VIS spectrophotometer (PG Instruments Limited, UK) for the biochemical studies.

\section{Hormonal Study}

Estimation of serum testosterone hormone was carried out using diagnostic kit purchased from DPC Company, USA, as described by Yen and Jaffe (26). Serum FSH concentration was estimated using a double antibody radio-immuno-assay (RIA) Kit supplied by Diagnostic Products Corporation, USA, according to the method described by Moudgal and Madhwa (27). PRL hormone was determined by specific double antibody radio-immuno-assay Kit supplied by Diagnostics Products Corporation, USA, as described by Djursing et al. (28) using gamma counter (Auto Gamma Counter, Cobra II, Packard Instrument, USA).The levels of the hormones were calculated according to standard curves.

\section{Sperm count}

The cauda epididymis was cautiously detached from the testis and minced in $1 \mathrm{ml}$ of phosphate buffered saline (PH 7.2) to obtain a suspension which was dispersed and filtrated to exclude tissue fragments (29). Sperm count was calculated by standard method in Neubauer's chamber (30).

\section{Histological investigations}

Small pieces of testes were fixed in 10\% buffered formalin and embedded in paraffin. Sections of $5 \mathrm{~mm}$ were cut and stained with hematoxylin and eosin. Tissue sections were then examined under light microscope (Olympus-Laboratory Binocular (LED) Microscope Model: CX23- Japan) at a magnification 400x.

\section{Data statistical analysis}

The data were presented as mean \pm S.E. Statistical analysis was performed using one-way analysis of variance (ANOVA). Statistical package of social science (SPSS) version 15.0 was used for windows. Individual difference among groups was analysed by Duncan $s$ test. Significance was indicated at $\mathrm{P}<0.05$.

\section{RESULTS}

Animals treated with melatonin (MLT) suffered no complications during the experimental period. No significant differences were observed between control and MLT groups in body weight, testicular weight, epididymis weight, seminal vesicles and ventral prostate weights. However, in cypermethrin groups, and irradiated rats, the previous parameters were significantly lowered compared to those of control and MLT. In group MLT + (cypermethrin or radiation), a noticed significant amelioration of organs weight to approximate normal state by the use of melatonin (table 1).

The results presented in table 2 showed that whole body $\gamma$-irradiation of rats at a dose of $8 \mathrm{~Gy}$ or administered with cypermethrin induced significant increases in concentrations of (TBARS) and $\left(\mathrm{H}_{2} \mathrm{O}_{2}\right)$ level in testis homogenate as compared with corresponding control group while, a significant decrease was observed in the activities of (CAT), (SOD), and (GSH) level in rats testis as associated with corresponding control group. The obtained findings showed that MLT pre-treatment markedly decreased (TBARS) and $\left(\mathrm{H}_{2} \mathrm{O}_{2}\right)$ levels compared with corresponding cypermethrin or $\boldsymbol{\gamma}$-irradiation group, as well as significantly increased (GSH) level and (CAT), (SOD) activities compared with corresponding cypermethrin or $\boldsymbol{\gamma}$-radiation group.

The results of this study revealed that whole body g-radiation of rats / or rats administered with cypermethrin pesticide resulted in hormonal disorders. These disorders were 
manifested by a significant elevation in serum FSH and prolactin hormones accompanied by drastic significant inhibition in serum testosterone hormones as compared with the corresponding group of control.

Table 1. Effect of MLT, $\gamma$-irradiation or cypermethrin on body weight, testes weight, epididymis weight, seminal vesicles and ventral prostate weights in male rats.

\begin{tabular}{|c|c|c|c|c|c|}
\hline Groups & $\begin{array}{c}\text { Body weight } \\
\text { (g) }\end{array}$ & \begin{tabular}{|c|}
$\begin{array}{c}\text { Testis wt (mg/100 } \\
\text { body wt) }\end{array}$ \\
\end{tabular} & $\begin{array}{l}\text { Epididymis } \\
\text { (mg) }\end{array}$ & $\begin{array}{c}\text { Seminal vesicles } \\
\text { (mg) }\end{array}$ & $\begin{array}{c}\text { Ventral prostate } \\
\text { (mg) }\end{array}$ \\
\hline Control & $136 \pm 9.2$ & $830 \pm 15.00$ & $362 \pm 18.20$ & $862 \pm 17.13$ & $244 \pm 16.35$ \\
\hline MLT & $137 \pm 9.4$ & $833 \pm 18.00$ & $363 \pm 18.13$ & $864 \pm 17.19$ & $245 \pm 15.10$ \\
\hline cypermethrin & $\begin{array}{c}119 \pm 7.6 \\
a *\end{array}$ & $\begin{array}{c}780 \pm 11.91 \\
a * *\end{array}$ & $\begin{array}{c}316 \pm 11.41 \\
a * *\end{array}$ & $\begin{array}{c}801 \pm 10.99 \\
a * *\end{array}$ & $\begin{array}{r}220 \pm 5.30 \\
a^{*}\end{array}$ \\
\hline Radiation & $\begin{array}{c}108 \pm 6.2 \\
a^{* *}\end{array}$ & $\begin{array}{r}733 \pm 8.30 \\
a^{* *} \\
\end{array}$ & $\begin{array}{c}309 \pm 10.07 \\
a^{* *}\end{array}$ & $\begin{array}{r}791 \pm 9.25 \\
a^{* *}\end{array}$ & $\begin{array}{r}200 \pm 4.15 \\
a^{*}\end{array}$ \\
\hline MLT + cypermethrin & $\begin{array}{c}132 \pm 9.1 \\
b *\end{array}$ & $\begin{array}{c}826 \pm 16.21 \\
b * *\end{array}$ & $\begin{array}{c}359 \pm 16.13 \\
b *\end{array}$ & $\begin{array}{c}857 \pm 14.40 \\
b *\end{array}$ & $\begin{array}{r}240 \pm 13.22 \\
b *\end{array}$ \\
\hline MLT + Rad & $\begin{array}{c}129 \pm 8.3 \\
c^{*}\end{array}$ & $\begin{array}{r}823 \pm 13.55 \\
c * * *\end{array}$ & $\begin{array}{c}355 \pm 15.70 \\
c^{*}\end{array}$ & $\begin{array}{r}854 \pm 14.42 \\
c^{* *}\end{array}$ & $\begin{array}{r}236 \pm 12.15 \\
c^{*}\end{array}$ \\
\hline
\end{tabular}

$a=$ significantly different as compared to control. $b=$ significantly different as compared to corresponding cypermethrin group. $c=$ significantly different as compared to corresponding radiation group. ${ }^{*},{ }^{* *}, * * *=\mathrm{P}<0.05, \mathrm{P}<0.01, \mathrm{P}<0.001$, respectively. Each value represents mean \pm SEM of 6 rats.

Table 2. Effect of MLT, $p$-irradiation or cypermethrin on levels and activities of testicular oxidative stress parameters in male rats.

\begin{tabular}{|c|c|c|c|c|c|}
\hline Groups & $\begin{array}{c}\text { TBARS } \\
\mathrm{n} \mathrm{mol} / \mathrm{mg} \text { protein }\end{array}$ & $\begin{array}{c}\text { GSH } \\
\text { n mol/g Tissue }\end{array}$ & $\begin{array}{c}\text { SOD } \\
\mathrm{U} / \mathrm{mg} \text { Protein }\end{array}$ & $\begin{array}{c}\text { CAT } \\
\mathrm{mU} / \mathrm{mg} \text { protein }\end{array}$ & $\begin{array}{c}\mathrm{H}_{2} \mathrm{O}_{2} \\
\mathrm{n} \text { mol/g Protein }\end{array}$ \\
\hline Control & $172 \pm 22$ & $88.5 \pm 12.2$ & $22.5 \pm 1.3$ & $102.3 \pm 5.5$ & $21.8 \pm 4.4$ \\
\hline MLT & $169 \pm 18$ & $86.2 \pm 11.3$ & $22.8 \pm 1.2$ & $100.1 \pm 3.3$ & $22.4 \pm 2.1$ \\
\hline cypermethrin & $\begin{array}{c}261 \pm 43 \\
a^{* * *}\end{array}$ & $\begin{array}{c}55.7 \pm 7.2 \\
a * *\end{array}$ & $\begin{array}{c}14.7 \pm 1.3 \\
a^{* *}\end{array}$ & $\begin{array}{c}83.8 \pm 7.8 \\
a *\end{array}$ & $\begin{array}{c}42.9 \pm 5.5 \\
a * * *\end{array}$ \\
\hline Radiation & $\begin{array}{c}255 \pm 40 \\
a * * *\end{array}$ & $\begin{array}{c}48.8 \pm 6.3 \\
a * *\end{array}$ & $\begin{array}{c}13.2 \pm 1.1 \\
\mathrm{a} * *\end{array}$ & $\begin{array}{c}87.3 \pm 8.2 \\
a^{*}\end{array}$ & $\begin{array}{c}48.6 \pm 7.7 \\
a * * *\end{array}$ \\
\hline MLT + cypermethrin & $\begin{array}{c}179 \pm 25 \\
b * *\end{array}$ & $\begin{array}{c}77.8 \pm 9.3 \\
b * *\end{array}$ & $\begin{array}{c}19.2 \pm 1.5 \\
b^{*}\end{array}$ & $\begin{array}{r}96.5 \pm 5.6 \\
b *\end{array}$ & $\begin{array}{r}24.8 \pm 4.7 \\
b * *\end{array}$ \\
\hline MLT + Rad. & $\begin{array}{r}184 \pm 29 \\
c^{* * *}\end{array}$ & $\begin{array}{r}73.5 \pm 8.8 \\
c^{* *}\end{array}$ & $\begin{array}{r}20.2 \pm 1.1 \\
c * *\end{array}$ & $\begin{array}{r}93.7 \pm 7.1 \\
c^{*}\end{array}$ & $\begin{array}{r}27.5 \pm 5.5 \\
c * *\end{array}$ \\
\hline
\end{tabular}

$a=$ significantly different as compared to control. $b=$ significantly different as compared to corresponding cypermethrin group. $c=$ significantly different as compared to corresponding radiation group. ${ }^{*}, * *, * * * \mathrm{P}<0.05, \mathrm{P}<0.01, \mathrm{P}<0.001$, respectively. Each value represents mean \pm SEM of 6 rats.

Oral supplementation of rats with MLT for 29 successive days to g-radiation exposed group / or administered with cypermethrin pesticide minimized the severity of changes induced in hormones level showing an increased level in serum testosterone with subsequent inhibition in serum FSH and prolactin hormones compared with corresponding cypermethrin or g-radiation group (table 3).

The data of the present investigation revealed that whole body $\gamma$ irradiation of rats / or rats administration with cypermethrin pesticide resulted in a significant decrease in both average sperm counts and motile sperms and a significant increase in average abnormal sperm forms compared to the control rats. It is worthy to indicate that the following up of the MLT pre-treatment at the end of 29 days, showed significant changes towards restoration of sperm quality to approximate that of the control values (table 4). 
Table 3. Effect of MLT, $y$-irradiation or cypermethrin on serum testosterone, $\mathrm{FSH}$ and prolactin hormones in male rats.

\begin{tabular}{|c|c|c|c|}
\hline Groups & $\begin{array}{c}\text { Testosterone } \\
\text { (Pg/ml.) }\end{array}$ & $\begin{array}{c}\text { FSH } \\
\text { (mlu/ml.) }\end{array}$ & $\begin{array}{c}\text { Prolactin } \\
\text { (ng/ml.) }\end{array}$ \\
\hline Control & $4.66 \pm 0.55$ & $5.52 \pm 0.74$ & $7.15 \pm 0.55$ \\
\hline MLT & $4.20 \pm 0.42$ & $6.21 \pm 0.83$ & $9.76 \pm 0.76$ \\
\hline cypermethrin & $\begin{array}{c}3.22 \pm 0.50 \\
\mathrm{a}^{*}\end{array}$ & $\begin{array}{c}8.42 \pm 1.11 \\
\mathrm{a}^{* *}\end{array}$ & $\begin{array}{c}10.04 \pm 0.61 \\
\mathrm{a}^{* *}\end{array}$ \\
\hline Radiation & $\begin{array}{c}2.75 \pm 0.40 \\
\mathrm{a}^{* *}\end{array}$ & $\begin{array}{c}9.21 \pm 1.32 \\
\mathrm{a}^{* * *}\end{array}$ & $\begin{array}{c}11.83 \pm 1.02 \\
\mathrm{a}^{* * *}\end{array}$ \\
\hline MLT+ & $\begin{array}{c}4.02 \pm 0.64 \\
\text { cypermethrin }\end{array}$ & $\begin{array}{c}5.66 \pm 0.57 \\
\mathrm{~b}^{*}\end{array}$ & $\begin{array}{c}7.01 \pm 0.48 \\
\mathrm{~b}^{* *}\end{array}$ \\
\hline MLT+ Rad & $\begin{array}{c}3.85 \pm 0.44 \\
\mathrm{c}^{*}\end{array}$ & $\begin{array}{c}5.35 \pm 47 \\
\mathrm{c}^{* *}\end{array}$ & $\begin{array}{c}6.85 \pm 0.36 \\
\mathrm{c}^{* * *}\end{array}$ \\
\hline
\end{tabular}

$a=$ significantly different as compared to control. $b=$ significantly different as compared to corresponding cypermethrin group. $\mathrm{c}=$ significantly different as compared to corresponding radiation group. ${ }^{*}, * * * * *=\mathrm{P}<0.05, \mathrm{P}<0.01, \mathrm{P}<0.001$, respectively. Each value represents mean \pm SEM of 6 rats.

\section{Histological examination}

The normal histological structure of testicular tissue section in normal rat was observed with normal configuration of seminiferous tubules with its interstitial spaces. The convoluted tubule wall consists of an outer connective tissue coat with flattened cells (basal lamina) and a lining stratified epithelium forming the germinal epithelium which forms the vast majority of the cells in the tubules. There are sertoli cells standing at intervals on the basal lamina and in between them the germ cells with five or six layers. Next to the basal lamina lie the spermatogonia and beside them are the spermatocytes formed from the spermatogonia. The division of spermatocytes leads to spermatids (as small round cells) which may develop to spermatozoa (figure 1).

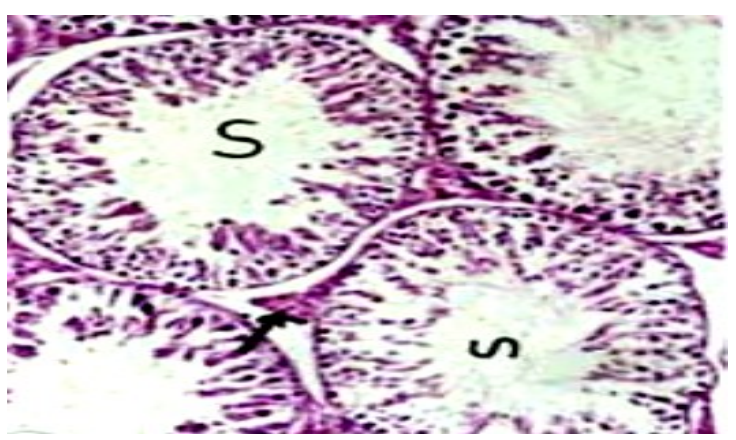

Figure 1. A testicular section in normal rat showing the normal configuration of seminiferous tubules with its interstitial spaces ( $\mathrm{Hx} \& \mathrm{E} . \mathrm{x} 400)$.
Table 4. Effect of MLT, $\gamma$-irradiation or cypermethrin on testicular sperm count, motile sperms and abnormal forms in male rats.

\begin{tabular}{|c|c|c|c|}
\hline Groups & $\begin{array}{c}\text { Sperm counts } \\
(\mathrm{X} \mathrm{10} / \text { epididymis }\end{array}$ & $\begin{array}{c}\text { Motile sperms } \\
\text { (Count/3000) }\end{array}$ & $\begin{array}{c}\text { Abnormal forms } \\
\text { (Count/3000) }\end{array}$ \\
\hline Control & $33.4 \pm 2.97$ & $2562 \pm 319.8$ & $22.3 \pm 3.02$ \\
\hline MLT & $32.7 \pm 2.72$ & $2379 \pm 222.2$ & $21.8 \pm 2.50$ \\
\hline \multirow{2}{*}{ cypermethrin } & $22.5 \pm 2.15$ & $1595 \pm 200.31$ & $173.9 \pm 22.15$ \\
& $a^{* *}$ & $a^{* * *}$ & $a^{* * *}$ \\
\hline \multirow{2}{*}{ Radiation } & $24.2 \pm 2.43$ & $\begin{array}{c}1386 \pm 222.08 \\
a^{* *}\end{array}$ & $\begin{array}{c}194.8 \pm 29.22 \\
a^{* * *}\end{array}$ \\
\hline MLT+ & $30.3 \pm 2.4$ & $2310 \pm 214.4$ & $64.5 \pm 6.11$ \\
cypermethrin & $b^{* *}$ & $b^{* * *}$ & $b^{* *}$ \\
\hline \multirow{2}{*}{ MLT+ Rad } & $29.2 \pm 2.2$ & $2168 \pm 227.5$ & $81.6 \pm 7.94$ \\
& $c^{*}$ & $c^{* * *}$ & $c^{* *}$ \\
\hline
\end{tabular}

$a=$ significantly different as compared to control. $b=$ significantly different as compared to corresponding cypermethrin group. $\mathrm{c}=$ significantly different as compared to corresponding radiation group. $*, * *, * * *=\mathrm{P}<0.05, \mathrm{P}<0.01, \mathrm{P}$ $<0.001$, respectively. Each value represents mean \pm SEM of 6 rats.

No pathological changes were noticed in the testicular tissue section of melatonin treated rats showing the normal configuration of seminiferous tubules with its interstitial spaces (figure 2).

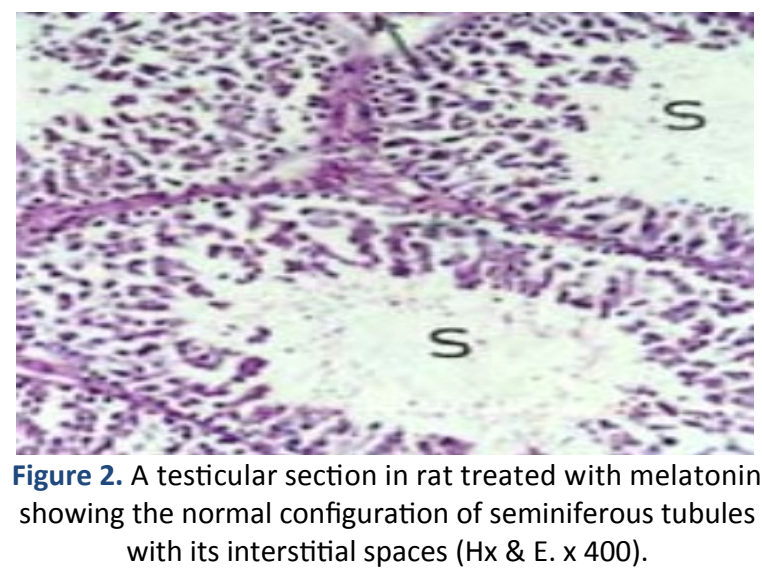

The testicular tissue section of rats exposed to $\gamma$-radiation fractionated doses and dissected on the $29^{\text {th }}$ day of the experiment displayed the vasting of the interstitial spaces between seminiferous tubules with ruptured connective tissue. The tubules revealed different stages of spermatogania to spermatocytes. The epithelial layer of the basement membrane in between two tubules was ruptured and showed deterioration in some portions (figure 3).

An investigation of a testicular tissue of rats treated with cypermethrin and dissected on the

Int. J. Radiat. Res., Vol. 18 No. 4, October 2020 
$29^{\text {th }}$ day of the experiment exhibited an extending in the interstitial spaces between the tubules with ruptured connective tissue. The epithelial cells of the basement membrane was ruptured in few semniferous tubules. The inspection of spermatognia revealed dividing in the spermatocytes and even spermatids revealed numerous and in meiosis (figure 4).

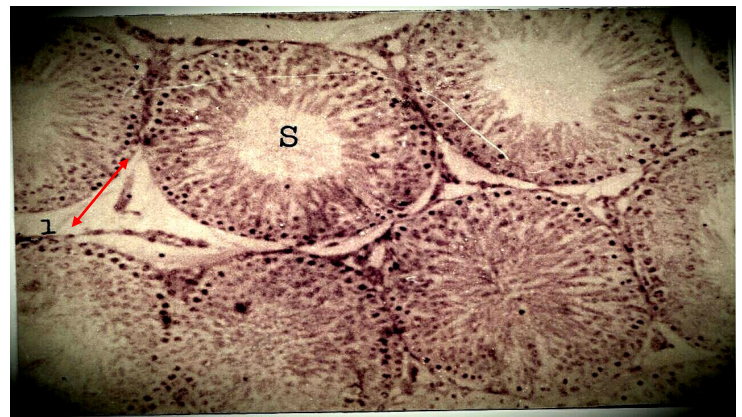

Figure 3. A micrograph of seminiferous tubules (s) of rat testis exposed to $\gamma$-radiation showed the widened interstitial spaces $(l \longleftrightarrow)$. The seminiferous tubules revealed deteriorated basement membrane (Hx \& E . x 400).

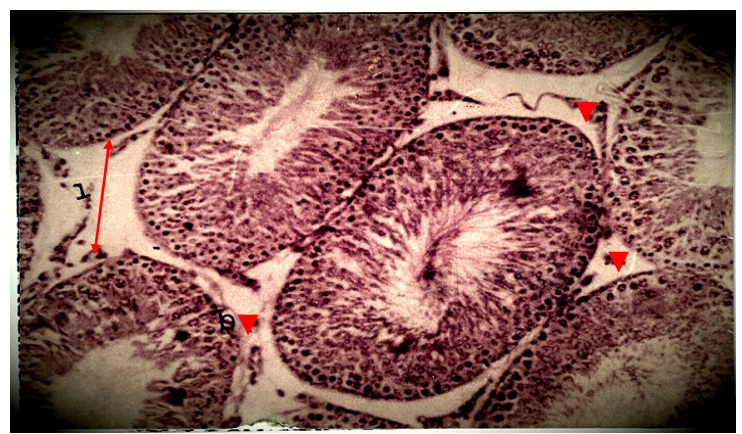

Figure 4. A micrograph of seminiferous tubules (s) of rat testis exposed to cypermethrin doses for 29 days exhibited deteriorated connective tissue in the vasted interstitial spaces ( $\mathrm{i} \longleftrightarrow$ ). the basement membrane layer (b) of the tubules was ruptured (Hx\& E. x 400).

The testicular tissue section of rats pre-treated with melatonin and exposed to $\gamma$-radiation for 29 days showed ameliorative effects as compared to those only irradiated, showing manifested variable changes in the interstitial spaces and spermatide nuclei (figure 5).

Also, the testicular tissue section of rats pre-treated with melatonin and treated with cypermethrin for 29 days exhibited an obvious repair mechanism in the basement membrane layer of the seminiferous tubule. Spermatogonia Int. J. Radiat. Res., Vol. 18 No. 4, October 2020 revealed various divisions (figure 6).

Histological examination clearly demonstrates that pre-treatment of male rats with melatonin ameliorated cypermethrin or $\gamma$-irradiation induced toxicity and decreased spermatogenic cells in rat testicles.

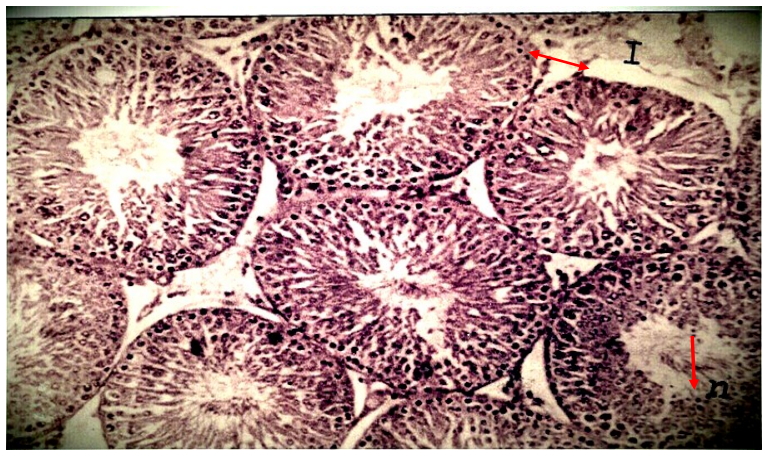

Figure 5. A micrograph of seminiferous tubules (s) and spermatocytes nuclei $(\mathrm{n})$ of rat testis pre-treated with melatonin and exposed to $\mathrm{y}$-radiation for 29 days showing the variable changes in the interstitial spaces and spermatide nuclei (Hx \& E. x 400).

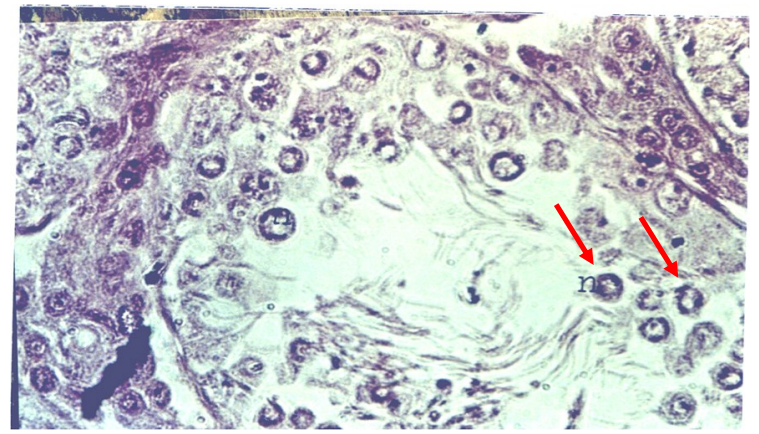

Figure 6. A micrograph of seminiferous tubules (s) and spermatocytes nuclei ( $\mathrm{n}$ ) of rat testis pre-treated with melatonin and administered cypermethrin for 29 days showed improvement in the testicular tissue by MLT ( $\mathrm{Hx} \& \mathrm{E} . \mathrm{x} 400)$.

\section{DISCUSSION}

Sterility has always been a main health and community concern. The defensive capability of chemicals in contradiction of male reproductive anomalies induced by radiation might suggest a novel understanding to alteration of testicular germ-cell radiosensitivity suggesting improvement of testicular damages (31).

Exposure of biological systems to ionizing radiation or pesticides may stimulate biological dysfunction through oxidative stress .Ionizing 
radiation exerts its deleterious effects in biological systems by starting ROS production through the radiolysis of water. ROS comprise $\mathrm{O}_{2}$-derived free radical including hydroxyl radical $(-\mathrm{OH})$ in addition to superoxide anion radical $\left(\mathrm{O}_{2}{ }^{-}\right)$and additionally non radical derivatives of $\mathrm{O}_{2}$ such as hydrogen peroxide $\left(\mathrm{H}_{2} \mathrm{O}_{2}\right)$. It is well-known that ionizing radiation causes damage to DNA, protein, carbohydrates as well as lipids in numerous tissues (32). Therefore, this study aimed at investigating the protective effects of melatonin on oxidative stress induced by either cypermethrin or $\gamma$-irradiation in rats and the subsequent testicular damage.

Reproductive tissue weights remain the standards for assessment of reproductive toxicity (33). In the current study, significant decreases have been observed in average body weight, testes weight, epididymis weight, seminal vesicles weight and ventral prostate weight in male rats treated with either cypermethrin or exposed to $\gamma$-radiation when compared to those of the control group. Similar results were found in this regard with the cypermethrin treated rats (34) where testis weight is mainly reliant on mass of differentiated spermatogenic cells, thus a decrease in testis weight might be owing to the reduced germ cells number and the number of the extended spermatids (35,36). Testicular steroidogenesis is managed by hypothalamopitutary axis, which may be distressed by poisonous contributions (37). The epididymis weight and adjunct sex tissues necessitate an incessant androgenic stimulus for their typical functions and development (38), thus a reduction was observed in reproductive tissues weight which reveals a failure in androgens bioavailability and generation. Additionally, administration of cypermethrin or exposure to radiation likewise led to a decline in the body weight. This reduction might be attributed to the toxic influence of cypermethrin or $\gamma$-irradiation on various body systems by expanding the free radical generation, hormonal imbalance and inhibition of enzymes function causing a general decrease of metabolic activity alongside the malabsorption of sustenance materials (39).
The data obtained in this study demonstrated that oral supplementation of rats with melatonin (MLT) only did not produce any significant changes in the body weight and other reproductive organs weight, the pre- treatment with MLT induced protection against deleterious effect of $\gamma$-irradiation or cypermethrin on all reproductive tissues in rat groups. Similar data to those of the present study were found by Mahdavi and Mozdarani (36) and Sharma et al. (40).

The present investigation had demonstrated that $\gamma$-irradiation or cypermethrin exerted an increase in the concentration of TBARS and $\mathrm{H}_{2} \mathrm{O}_{2}$ in the testes. These findings are in agreement with those of previous studies $(34,41)$.The increased TBARS was due to associations of oxygen radicals with polyunsaturated fatty acids residues in membrane phospholipids which impairs membrane functions by decreasing membrane permeability and changing the activity of membrane-bound enzymes and receptors (42). The elevated concentrations of TBARS in testicular tissues in cypermethrin or $\gamma$-irradiation groups are signs of lipoperoxidative variations, initiating functional and structural changes.

Reduction in testicular SOD and CAT activities were evident in the $\gamma$-irradiation or cypermethrin groups. These findings agree with those of previous studies (41,42). SODcatalyzes the dismutation of $\mathrm{O}_{2} \cdot-$ to $\mathrm{H}_{2} \mathrm{O}_{2}$ as it is the first line antioxidant defence in the body. The reduced SOD activity in cypermethrin or $\gamma$-irradiation group might be owing to reduced production, expanded deprivation and loss of enzyme activity. SOD is an essential antioxidant enzyme in the development or maturation of spermatozoa, it possess a crucial biological role in sperm motility (43). Thus, reduced testes SOD activity verified in cypermethrin or $\gamma$-irradiation group might likewise indirectly reveal its action on spermatozoa. Similarly, the observed decline in CAT activity in $\gamma$-irradiationor cypermethrin group could be owing to reduced conversion of $\mathrm{O}_{2 .-}$ to $\mathrm{H}_{2} \mathrm{O}_{2}$ by $\mathrm{SOD}$, formerly leads to accumulation of $\mathrm{O}_{2 .}-$ which is revealed in inhibiting CAT activity ${ }^{(42)}$ such as $\mathrm{O}_{2}$.- converts ferroxy state of CAT to ferryl state; the inactive

Int. J. Radiat. Res., Vol. 18 No. 4, October 2020 
enzyme form ${ }^{(44)}$. Also the depletion of GSH level may be attributed to either its utilization in the detoxification of $\mathrm{H}_{2} \mathrm{O}_{2}$ or reaction with $\mathrm{NO}$ or $\mathrm{ONOO}^{-}$to form S-nitrosoglutathione ${ }^{45)}$.This diminished antioxidant status denoted through CAT and SOD low activities, depletion of GSH level combined with lipoperoxidative variations in $\gamma$-irradiation or cypermethrin group is a clue of oxidative stress (33), leading to modification of sex hormones production terminating in diminished sperm count (46).

In this study, MLT pre- treatment reduced products of lipid peroxidation. Accordingly, it significantly increased the testicular GSH content, SOD and CAT activities which, in turn, reveal its strong antioxidant potential in counteracting free radical-mediated injury. These findings are consistent with the findings of previous studies ${ }^{40,41)}$.Besides MLT capability to scavenge hydroxyl radical (17), also it possesses effective detoxifying capacity to further ROS and reactive nitrogen species in addition to their metabolites, peroxynitrous acid, and intermediates $\mathrm{H}_{2} \mathrm{O}_{2}$ (47). Furthermore, MLT upregulate numerous antioxidant enzymes, thus boosts the antioxidant potential of the cell $(48,49)$. Since it was shown to stimulate the synthesis of the rate-limiting enzyme, $\gamma$-glutamylcysteine synthase, which inhibits the pero-oxidative enzymes nitric oxide synthase and lipoxygenase (50), MLT determines the total amount of cellular GSH due to its crucial role in maintaining GSH homeostasis within the cell. Besides, MLT has complementary role to GPx and CAT in maintaining concentrations of intracellular $\mathrm{H}_{2} \mathrm{O}_{2}$ at maintained steady levels (51).Thus, MLT is capable of ameliorating cypermethrin or $\gamma$-irradiationinitiated oxidative stress and exasperation of redox status within sperm and testicles.

In the present study, a significant elevation occurred in serum FSH and prolactin hormones accompanied by a drastic significant inhibition in serum testosterone hormone in animals group treated with cypermethrin or exposed to $\gamma$-radiation. This may be due to its correlation with sertoli cells dysfunction. Although the level of FSH increases possibly not due to a direct irradiation effect rather than secondary result of germ cell depletion. The alterations in testosterone and prolactin levels are indicative of leydig cell function-impairment (52). Besides, $\gamma$-irradiationcould influence testosterone and spermatogenesis through interfering with the neural mechanisms covering gonadotrophin synthesis or release (53). In the same context,treatment of rats with cypermethrin lowered testosterone level which could be attributed to testicular StAR expression downregulation (13). These inhibitory effects were confirmed with the results reported by Sharma et al. (40) and Tawfik etal. (53). The observed amelioration of MLT to hormonal disturbances caused by cypermethrin or $\gamma$-irradiation may be owing to MLT activity at several levels of the hypothalamic-pituitarygonadal axis (22). The present results are in agreement with those of Sharma et al (40) and Tawfik et al. (53).

One of the most vital parameters in assessing the fertilizing capacity of sperm is sperm motility which assess and evaluate the coordinate potential for reproductive toxicity of the pesticide cypermethrin or exposure to $\gamma$-radiation. The finding of $\gamma$-irradiation or cypermethrin impacts on sperm count, motile sperm count and abnormal forms is in agreement with that of El-Dawi et al (54) who found a significant increase of abnormal forms in animals exposed to $\gamma$-radiation, which prompted testicular damage, germ cell dysfunction and spermatogenesis impedance due to the high sensitivity of proliferating spermatogonia to ionizing radiation. Similarly, Joshi et al (34) observed that treatment with cypermethrin was able to adversely affect sperm viability, sperm motility, and increased sperm anomaly. Also Li et al. (55) noticed a significantly increase in the level of sperm head anomalies number in cypermethrin treated rats. Prompted sperm abnormalities demonstrate point mutations in germ cell, which ought to activate structural changes in cell organelles involved in head and tail formation, prompting sperm abnormalities. The present results are in agreement with the previously discussed data which correlated the effect of the oxidative stress initiated by cypermethrin or $\gamma$-irradiation, 
spermatogenesis disruption and abnormal forms production, In addition to this, the current study verifies that pre-treatment of rats with melatonin (MLT) and $\gamma$-irradiation or cypermethrin exerted good effect on sperm count, motile sperms and sperm abnormalities owing to its powerful antioxidant capacity. These effects were confirmed with the results reported by El-Dawi et al. (54), Sharma et al. (56).

Finally, the obtained biochemical findings were confirmed by the histopathological examination in the testes, where pre-treatment with MLT provides protection against $\gamma$-irradiation or cypermethrin induced testicular damage.

\section{CONCLUSION}

The present study suggests that prophylactic administration of melatonin (MLT) might be beneficial in reducing the severity of radiation or pesticide injury in testicular organs in rats.

\section{ACKNOWLEDGMENT}

Thanks to Dr. Mona Galal Abd El Azeem Prof. of histology, the NCRRT.

\section{Authors' contributions}

All authors Elhamy.M. Kamal El-Dein and Lobna.M. Anees designed the study, performed the experimental works on the rats. Lobna.M. Anees wrote the manuscript. Elhamy.M. Kamal El-Dein analyzed the data. All authors revised and approved the manuscript.

\section{Conflicts of interest: Declared none.}

\section{REFERENCES}

1. Bungum M (2012) Sperm DNA integrity assessment: A new tool in diagnosis and treatment of fertility. Obstet Gynecol Int, Article ID: 531042, 6 pages.

2. Venkatachalam P, de Toleddo S, Azzam E (2005) Flavin containing oxidases regulate progression from $\mathrm{G} 1$ to $\mathrm{S}$ phase of the cell cycle in normal human diploid fibroblasts. Rad Physic Chem, 72: 315.

3. Agarwal A, Gupta S, Sikka S (2006) The role of free radicals and antioxidants in reproduction. Current Opinion in $\mathrm{Ob}$ stetrics and Gynecology, 18(3): 325-332.

4. Chen H, Liu J, Luo L, Baig MU, Kim JM, Zirkin BR (2005) Vitamin E, aging and Leydig cell steroidogenesis. Experimental Gerontology, 40(8-9): 728-736.

5. Aitken RJ and De luliis GN (2007) Origins and consequences of DNA damage in male germ cells. Reproductive BioMedicine Online, 14(6): 727-733.

6. El-Khafif M, Ragab M, El-Dawy H, Tawfik S (2003) Effect of taurine treatment on some biochemical parameters in gamma irradiated mice. Environ Sci, 6(2): 393.

7. Wang XZ, Liu SS, Sun Y, Wu JY, Zhou YL, Zhang JH (2009) Beta- cypermethrin impairs reproductive function in male mice inducing oxidative stress. Theriogenology, 72: 599611.

8. Han Y, Xia Y, Han J, Zhou J, Wang S, Zhu P, et al. (2008); The relationship of 3-PBA pyrethroids metabolite and male reproductive hormones among non-occupational exposure males. Chemosphere, 72: 785-9.

9. Kojima H, Katsura E, Takeuchi S, Niiyama K, Kobayashi K ( 2004) Screening for estrogen and androgen receptor activities in 200 pesticides by in-vitro reporter gene assays using Chinese hamster ovary cells. Environ Health Perspect, 112: 524-31.

10. Song L, Wang YB, Sun H, Yuan C, Hong X, Qu JH, et al. (2008); Effects of fenvalerate and cypermethrin on rat sperm motility patterns in-vitro as measured by computerassisted sperm analysis. J Toxicol Environ Health A, 71: 325 -32 .

11. Bhunya SP and Pati PC (1988) Genotoxic effects of synthetic pyrethroid insecticide Cypermethrin in mice in vivo. Toxicol Lett, 41(3): 223-230.

12. Hu JX, Li YF, Li J, Pan C, He Z, Dong HY, et al. (2013) Toxic effects of cypermethrin on the male reproductive system: With emphasis on the androgen receptor. J Appl Toxicol, 33: 576-85.

13. Wang $\mathrm{H}$, Wang $\mathrm{Q}$, Zhao $\mathrm{XF}$, Liu $\mathrm{P}$, Meng $\mathrm{XH}, \mathrm{Yu} \mathrm{T}$, et al. (2010) Cypermethrin exposure during puberty disrupts testosterone synthesis via downregulating StAR in mouse testes. Arch Toxicol, 84: 53-61.

14. Reiter RJ, Tan DX, Osuna C, Gitto E (2000) Actions of melatonin in the reduction of oxidative stress. Journal of Biomedical Science, 7: 444-458.

15. Pandi-Perumal SR, Srinivasan V, Maestroni GJ, Cardinali $D$ P, Poeggeler B, Hardeland R (2006) Melatonin: nature's most versatile biological signal? The FEBS Journal, 273: 2813-2838.

16. Li B, He X, Zhuang M, Niu B, Wu C, Mu H, et al. (2018) Melatonin ameliorates busulfan-induced spermatogonial stem cell oxidative apoptosis in mouse testes. Antioxid Redox Signal, 28(5): 385-400.

17. Reiter RJ, Tan DX, Gitto E, Sainz RM, Mayo JC, Leon J, et al. (2004) Pharmacological utility of melatonin in reducing oxidative cellular and molecular damage. Polish Journal of

Int. J. Radiat. Res., Vol. 18 No. 4, October 2020 
Pharmacology, 56: 159-170.

18. Kotler M, Rodriguez C, Sainz RM, Antolín I, MenéndezPeláez A (1998) Melatonin increases gene expression for antioxidant enzymes in rat brain cortex. Journal of Pineal Research, 24: 83-89.

19. US EPA (1989), Pesticide fact sheet number 199: cypermethrin. Office of Pesticides and Toxic Substances, Washington, DC, pp 2-9

20. El-Missiry MA, Fayed TA, El-Sawy MR, El-Sayed AA (2007) Ameliorative effect of melatonin against gamma irradiation-induced oxidative stress and tissue injury. Ecotoxicology and Environmental Safety. 66: 278-286.

21. Yoshioka T, Kawada K, Shimada T, Mori M (1979) Lipid peroxidation in material cord blood and protective enzyme against activated oxygen toxicity in the blood. Am J Obestet Gynecol, 135(3): 372.

22. Beutler E, Duron O, Kelly BM (1963) Improved method for determination blood glutathione. J Lab Clin Med, 61(5): 882.

23. Pick $E$ and Keisari $Y$ (1981) Superoxide anion and $\mathrm{H}_{2} \mathrm{O}_{2}$ production by chemically elicited peritoneal macrophagesinduced by multiple non phagocytic stimuli. Cell Immunol, 59: 301.

24. Minami $M$ and Yoshikawa $H$ (1979) Asimplified assay method of superoxide dismutase activity for clinical use. Clin Chem Acta, 92: 337.

25. Johansson LH and Borg HL (1988) A spectrophotometric Method for determination of catalase activity in small tissue samples. Analyt Biochem, 174: 331.

26. Yen SSC and Jaffe RB (1978) Edd, Reproductive Endocrinology. (W.B. Saunders)

27. Moudgal NR and Madhwa Raj HG (1974) Pituitary gonadotrophins. In: Jaffe BM, Behrman HR, editor Methods of Hormone Radioimmunoassay. New York: Academic Press; pp. 67-85.

28. Djursing H, Hagen C, Muller J, Christiansen C (1981) Short and long term fluctuation in plasma prolactin concentration in normal subjects Acta Endocrinol, 97: 1-6.

29. Narayana K, D' Souza UJA, Rao KPS (2002) Ribavirin induced sperm shape abnormalities in Wister rat. Mutat Res, 513(1-2): 193-196.

30. Vega SG, Guzman P, Garcia L, Espinosa J, De Nava CC (1988) Sperm shape abnormality and urine mutagenicity in mice treated with niclosamide. Mutal Res, (204): 269- 276.

31. Weiss JF and Landauer MR (2009) History and development of radiation-protective agents. Int J Radiat Biol, 85: 539-573.

32. Chen CZ, Xu F, Zhu C, Fang F, Shu S, Li M, Ling C (2013) Radio-Protective effect of catalpol in cultured cells and mice. J Radiat Res, 54-76.

33. Zidan NA (2009) Evaluation of the reproductive toxicity of chlorpyrifos methyl, diazinon and profenofos pesticides in male rats. Inter J Pharmacol, 5(1): 51-57.

34. Joshi SC, Bansal B, Jasuja ND (2011) Evaluation of reproductive and developmental toxicity of cypermethrin in male albino rats. Toxicol Environ Chem, 93: 593-602.

35. Aoyama H, Hojo H, Takahashi KL, Shimizu-Endo N, Araki M,Takeuchi-Kashimoto $\mathrm{Y}$ et al. (2012) Two-generation

Int. J. Radiat. Res., Vol. 18 No. 4, October 2020 reproduction toxicity study in rats with methoxychlor. Congenit Anom (Kyoto) 52: 28-41.

36. Mahdavi M and Mozdarani H (2011) Protective effects of famotidine and vitamin $\mathrm{C}$ against radiation induced cellular damage in mouse spermatogenesis process. Int J Radiat Res, 8 (4): 223-230.

37. Singh SK and Pandey RS (1989) Differential effects of chronic endosulfan exposure to male rats in relation to hepatic drug metabolism and androgen biotransformation. Indian J Biochem Biophys, 26: 262-267.

38. Hu GX, Zhao B, Chu Y, Li XH, Akingbemi BT, Zheng ZQ, Ge RS (2011) Effects of methoxychlor and 2, 2-bis (phydroxyphenyl)1,1,1-trichloroethane on $3 \beta$ - hydroxyl steroid dehydrogenase and $17 \beta$ - hydroxysteroid dehydrogenase-3 activities in human and rat testes. Int J Androl, 34: 138-144.

39. Nair N, Bedwal S, Prasad S, Saini MR, Bedwal RS (2005) Short-term zinc deficiency in diet induces increased oxidative stress in testes and epididymis of rats. Indian J Exp Biol, 43: 786-794.

40. Sharma P, Aslam KI, Singh R ( 2018) Curcumin and Quercetin Ameliorated Cypermethrin and Deltamethrin-Induced Reproductive System Impairment in Male Wistar Rats by Upregulating The Activity of Pituitary-Gonadal Hormones and Steroidogenic Enzymes. Int J Fertil Steril, 12(1): 72-80.

41. Shaban NZ, Ahmed Zahran AM, El-Rashidy FH, Abdo Kodous AS (2017) Protective role of hesperidin against $\gamma$ radiation-induced oxidative stress and apoptosis in rat testis. J Biol Res, (Thessalon). 1: 24:5.

42. Shittu M, Ayo JO, Ambali SF, Fatihu MY, Onyeanusi BI, Kawu MU (2012) Chronic chlorpyrifos-induced oxidative changes in the testes and pituitary glands of Wistar rats: Ameliorative effect of vitamin C. Pest Biochem Physiol, 102: 79-85.

43. Marzec-Wróblewska $U$, Kamiński $P$, Łakota $P$, Szymański M, Wasilow K, Ludwikowski G, et al. (2011) Zinc and iron concentration and SOD activity in human seminal plasma. Biol Trace Elem Res, 143 (1): 167-177.

44. Krishnamoorthy G, Ventaraman P, Arunkumar A, Vignesh RC, Aruldhas MM, Arunakaran J (2007) Ameliorative effect of vitamins ( $\alpha$ - tocopherol and ascorbic acid) on PCB (Aroclor 1254)-induced oxidative stress in rat epididymal sperm. Rep Toxicol, 23: 239-45.

45. Krishna A and Kumar A (2005) Evaluation of radioprotective effect of Rajira (Amaranthus paniculatus) extract in Swiss albino mice. J Radiat Res, 46: 233-239.

46. Fattahi E, Parivar K, Jorsaraei SGA, Moghadamnia AA (2009) The effects of diazinon on testosterone, FSH and LH levels and testicular tissue in mice. Iranian J Rep Med, 7 (2): 59-64.

47. Reiter RJ, Mayo JC, Tan DX, Sainz RM, Alatorre-Jimenez M, Qin L (2016) Melatonin as an antioxidant: under promises but over delivers. J Pineal Res, 61(3): 253-278.

48. Goc Z, Szaroma W, Kapusta E, Dziubek K (2017) Protective effects of melatonin on the activity of SOD, CAT, GSH-Px and GSH content in organs of mice after administration of SNP. Chin J Physiol, 60(1): 1-10.

49. Fischer TW, Kleszczynski K, Hardkop LH, Kruse N, Zillikens 
D (2013) Melatonin enhances antioxidative enzyme gene expression (CAT, GPx, SOD), prevents their UVR-induced depletion, and protects against the formation of DNA damage (8-hydroxy-20-deoxyguanosine) in ex vivo human skin. Journal of Pineal Research, 54: 303-312.

50. Urata Y, Honma S, Goto S, Todoroki S, lida T, Cho S, et al. (1999) Melatonin induces gamma-glutamylcysteine synthetase mediated by activator protein-1 in human vascular endothelial cells. Free radical Biology \& Medicine, 27: 838 $-847$.

51. Tan DX, Manchester LC, Reiter RJ, Plummer BF, Limson J, Weintraub ST, et al. (2000) Melatonin directly scavenges hydrogen peroxide: a potentially new metabolic pathway of melatonin biotransformation. Free Radical Biology \& Medicine, 29: 1177-1185.

52. Narayanasami MR, Puliyangudi BS, Ibrahim MJ, Perumal K,
Karundevi B (2006) Radiation exposure impairs luteinizing hormone signal transduction and steroidogenesis in cultured human leydig cells. Toxicological Sci, 91: 550.

53. Tawfik SS, Mansour HH, El Shamy E (2006) Radioprotective effect and follow-up of melatonin as antifertility drug in male adult mice submitted to whole body gamma irradiation. Egy J Rad Sci Appl, 19(2): 331-351.

54. El-Dawi HA and Aly SE (2004) Radio-protective role of zinc administration pre-exposure to gamma- irradiation in male albino mice. Egypt J Rad Res Applic, 17(1): 13.

55. Li YF, Pan C, Hu JX, Li J, Xu LC (2013) Effects of cypermethrin on male reproductive system in adult rats. Biomed Environ Sci, 26: 201-8.

56. Sharma $P$, Huq AU, and Singh R (2014) Cypermethrininduced reproductive toxicity in the rat is prevented by resveratrol. J Hum Reprod Sci, 7(2): 99-106. 